\title{
Nepal: From Constitutional Monarchy to a Republican State (1990-2008)
}

\author{
Tri Ratna Manandhar \\ Tribhuvan University \\ Nepal
}

\begin{abstract}
The peoples' movement of 1990 was a great landmark in the history of modern Nepal for it ended the three-decades of the old dictatorial rule of the king and established a parliamentary system with the king as a nominal head of state. But unfortunately, the country could not form a good government because of inter and intra-party conflicts. To add fuel to the flame, the rise of the Maoist movement and the royal massacre put the country in a state of confusion and uncertainty. The new king tried to revive dictatorial rule once again by suppressing the political parties and the Maoists. But his attempts failed, and the 19day movement in 2006 re-established peoples' sovereignty in the country. The first meeting of the elected constituent assembly in 2008 formally ended monarchy and declared Nepal a republic. But the first constituent assembly ended its four-year term without drafting a constitution. The second constituent assembly has pledged to promulgate a democratic constitution by January 2015, but all indications are that that the country is unlikely to get a constitution in time.
\end{abstract}

Keywords: Nepal, Constitution, Monarchy, Republic, Politics.

\section{Introduction}

This paper attempts to make an objective assessment of the democratic experiments in Nepal since the movement of 1990 which after eighteen years finally led to the abolition of monarchy and foundation of a republican Nepal. It tries to analyze the circumstances behind the political instability in the country, the undeclared suspension of the constitution, and finally the mass movement of April 2006, which eventually abolished monarchy in Nepal.

\section{The Aftermath of the 1990 Movement}

The 1990 movement was a landmark in the political history of Nepal. Directed against the party less panchayat system functioning in Nepal for the last thirty years under the direct leadership of the king, it aimed at the restoration of multi-party system, that was briefly experimented in the country for eighteen months between the years 1959-60. The 1990 movement was a 50 - day movement that started on 18 February and ended on 8 April 1990, when King Birendra met the four leaders of the movement and gave assurances to fulfill 
their demands. Initiated by the two main political forces - the Nepali Congress (NC) and the United Left Front (ULF), the 1990 movement had the backing of almost all sections of the society - doctors, lawyers, literary figures, teachers, students, businessman, workers and peasants. Although the objectives of the movement were not clearly defined but its main purpose was for the return to multi-party system in Nepal. Though some participants of the movement raised ugly slogans against the royal family and monarchy, the meeting of the king with the four leaders on 8 April settled only one issue that was to delete the word "party less" from the constitution which automatically meant the open functioning of all banned political parties. Even the formal abolition of the panchayat system was not discussed, and after meeting with the king, the leaders announced the termination of the mass movement. But the situation completely changed the very next day, when at a mass gathering at Tudikhel, the speakers pledged not to take rest until a fully democratic political system was restored. The gathering at Tudikel was so emotional that when one NC leader argued the restoration of democracy as a victory for not only the people but also the king and the Panchas, he was booed and almost physically assaulted. Under the circumstances, the king was once again compelled to bow down to the people's demands, and an interim government headed by Krishna Prasad Bhattarai, the NC president, with nominees from the NC, ULF, the palace, and a few independents was formed on 19 April 1990. ${ }^{1}$

After the formation of the interim government, various political parties and interested groups began to make numerous demands regarding the new constitution, and in this changed context, emerged a number of new parties representing ethnic, religious, and regional concerns. On 24 April, the NC and ULF jointly issued the following statement on what the future constitution should be.

The new constitution must be fully democratic, the king must become a constitutional monarch, and he must act only on the advice of the cabinet. All institutions and laws not conductive to democratization must be repealed. A free election must be held as soon as possible and an independent election commission must be formed for this purpose. There should be press and academic freedom and equal rights for women. ${ }^{2}$

The two main parties, however, differed on the constitution making process. The ULF demanded the promulgation of an interim constitution till a permanent constitution could be framed by an elected constitutional assembly, but the NC dismissed the idea of the constitutional assembly as an "intellectual luxury" and argued that the interim constitution and the election of a constituent assembly would delay the general election. The ULF then modified its stand on the constituent assembly election, when even the former Panchas (supporters of the king's dictatorial rule for 30 years) and independent intellectuals began making demands for an elected constituent assembly. The ULF realized that the supporters of the panchayat system were only exploiting the situation to their favour by creating an atmosphere of instability, and thus agreed to participate in the constitution drafting committee along with the NC. ${ }^{3}$ 
On 11 May 1990, King Birendra constituted a seven-man constitution reform recommendation committee without consulting the interim cabinet. It was a risky step possibly taken just to test the strength of the multi-party system and its supporters. But the committee was immediately challenged on two points: (1) the people wanted a new constitution altogether and not reforms to the 1962 Constitution, and (2) demanded why, only one seat was given to the NC and ULF while all the other members of the committee were drawn from the former Panchas or the administrators under the panchayat rule. K.P. Bhattarai was ready to accept the committee, because in his own words, the government would be free to reject or amend the new proposed constitution, but when the ULF and NC members refused to join the committee, once again the king had to restructure its composition and a new constitution recommendation commission was formed, consisting of six members from the $\mathrm{NC}$ and ULF, two as the king's nominees, with a supreme court judge as its chairman. ${ }^{4}$

The new commission received a number of suggestions from different political parties, socio-religious organizations, and people representing various professions. On the political set-up, there was consensus on a constitutional monarchy with a powerful cabinet, parliament controlling the activities of the executive, and sovereignty vested in the hands of the people. But there were wide differences on the question of language, religion, ethnicity and regional issues. Some of the notable demands in this connection were: (a) language other than Nepali should have the constitutional status and national recognition, (b) Nepal should not be declared a Hindu state, (c) there should be proportional representation of minority groups in the legislature, (d) sovereignty should be vested in the king, and he should appoint the commander-in-chief. The last point came through a circular issued in the name of the Nepal army.

The commission completed the draft by the end of August, and submitted it to the king on 10 September 1990. The king, in return, handed over the draft to the prime minister for consideration, keeping in view the suggestions made by different agencies and organizations. The inner circle of the cabinet made some modifications to the draft, chief among which was the constitutional guarantee to the constitutional monarchy, multi-party democracy, and parliamentary system.

Meanwhile, on 21 October 1990 the royal palace released a new draft constitution which was said to have been prepared in consultation with the prime minister. The new draft differed from the original one on many issues including the status of monarch and the reference to the mass movement in the preamble. Prime Minister Bhattarai categorically denied that the draft was made in consultation with him, and offered to resign, since he could not endorse the palace draft. In the face of popular anger, the palace draft was abandoned, but the cabinet included some of the clauses of the palace draft in the final version of the constitution which was formally promulgated by the king on 9 November $1990 .{ }^{5}$

The preamble was the most important part of the constitution. It clearly stated that the source of sovereign authority of Nepal was inherent in the people, and the constitution was 
promulgated in accordance with the desire of the Nepali people expressed through people's movement. It aimed to guarantee basic human rights to every citizen and to consolidate the adult franchise, parliamentary system, constitutional monarchy, and multi-party democracy.

Despite opposition from the Buddhist, Muslim, and Christian organizations and ethnic groups representing non-Hindus, Nepal was declared a Hindu state. Nepali was declared to be the state language, but the other languages spoken in different parts of Nepal were also recognized as the national languages (Art.6.2). Emphasis was given on the point that "each community shall have right to operate schools up to the primary level in its own mother tongue for imparting education to their children" (Art. 8.2).

The king was declared purely a constitutional head of state, and enjoyed no substantial power of the state or in the government. Though mentioned as "the symbol of Nepalese nationality and the unity of the Nepalese people" (Art. 27.2), the king's discretionary and exclusive powers were mentioned only in few places viz, right to enact, amend, and repeal the law relating to succession to the throne (Art. 28.2), right to make rules relating to the condition of service of employees of the royal palace (Art. 121), and authentication of decisions and orders issued in the name of the king (Art. 35.5). For all other functions he should act on recommendation of the cabinet or other specific organs. These organs were - constitutional council, national defence council and judicial council. In some specific matters, the king was to act on the direct recommendation of the prime minister.

The cabinet headed by the prime minister was the real executive of the country and it was collectively responsible to the lower house of parliament (Art. 36.4). It was given exclusive responsibility of issuing general directives, controlling and regulating the administration of the kingdom of Nepal (Art. 35.3), however the prime minister was duty bound to inform the king about the general state of affairs of the country, matters concerning peace and security in the country, matters of political, social, and administrative concerns, and matters concerning international relations; and also any other information the king might ask for (Art. 43.1). Similarly, the king "may make recommendations to, or appreciation of or admonitions to, the council of ministers on matters of national importance" (Art. 43.2).

The parliament consisted of two houses - National Assembly and House of Representatives, having the strength of 60 and 205 respectively. The national assembly was a permanent house, with $1 / 3$ of its members retiring in every two years (Art. 46.2). The lower house was directly elected by the people for five years. As per the parliamentary practice, the lower house was made powerful in some specific matters chief among them was the control over the activities of the council of ministers (Art. 36.4).

The independence of judiciary was fully recognized, and there was total freedom to form political parties provided that the constitution of a political party was democratic, and it must not restrict membership on the basis of religion, community caste or region (Art. 113.2). Similarly, fundamental rights of the people had to be clearly defined though some of 
them might be suspended during the emergency period (Art. 115.8). Parliament was free to amend the provision of the constitution, without prejudicing the spirit of the preamble (Art. 116.1), and the king (on the recommendation of the cabinet) was empowered to declare a state of emergency, but the same must be approved by the House of Representatives within three months (Art. 115) ${ }^{6}$.

\section{Political Experiments (1991-1998)}

The 1990 constitution came into operation on the day of its promulgation i.e. on 9th November 1990, and the working cabinet got the new constitutional status with the power to exercise the functions of the constitutional council until it was constituted, and to recommend the enactment of new laws till the parliament was convened. The first task of the cabinet, however, was to hold the general election which took place on 12 May 1991.

The main political parties contesting the election were the NC, the single largest party. The Nepal Communist Party-United Marxist Leninist (UML) was another large party, and wherever possible it made electoral alliance with other communist or left-leaning parties. The two parties with the same name i.e., National Democratic Party (NDP), though formed by two prime ministers of the Panchayat days, fought the election independently and separately, and the Sadbhavana Party (A Tarai-based party) also contested the election independently concentrating mainly on the Tarai areas.

The election result gave mandate to the NC to rule and UML to sit in opposition. As a ruling party, the position of NC was rather weak. It got 110 seats in the house of 205 and this narrow margin majority was a setback to the proper functioning of the government. The election performance of NC in the Kathmandu Valley was poor, as it secured only two seats out of ten, and this made the working of the government difficult in the capital-Kathmandu, the center of power politics.

Compared to it, the UML was in strong opposition having captured 82 seats (together with other left parties with whom the UML had electoral alliance). As the position of two panchayat parties (NDP) was poor, this made them to merge into one party. The performance of the Sadbhavana Party was not good, but with six seats in hand, the party could pose a threat to the government at least on regional issues of Tarai. ${ }^{7}$

One of the main features of the NC rule was the intra-party conflict which led to its fall without it completing the full term of five years. The conflict started during the general election itself, when K. P. Bhattarai, the prime ministerial candidate of the NC was defeated, and the party had to recommend another leader, Girija Prasad Koirala, an unwillingly candidate for the post of prime minister. Within a few months, Ganesh Man Singh, the supreme leader of the NC, complained that the prime minister encouraged clicks within the party, whereas the prime minister argued that the supreme leader was demanding lion's 
share for his supporters. The situation worsened when K. P. Bhattarai contested a byeelection in 1993 and was again defeated. But Prime Minister Koirala was charged with manipulating the election against Bhattarai, using the government resource and machinery, which he categorically denied. Whatever the truth may be, this incident led to the division of the NC into two factions in the lower house. This became obvious when 36 members of $\mathrm{NC}$ (opposed to the prime minister) abstained from the house at the time of voting the royal address, leading to the failure of the government to get majority in favour of the royal address. Koirala immediately resigned from premiership, and also recommended the dissolution of the house. Thus the NC rule ended within three years. ${ }^{8}$

The second general election that took place in November 1994 produced a hung parliament. The NC came down to second position, capturing only 83 seats, with the UML emerging as the largest party with 88 seats, but 15 short of the absolute majority. Mana Mohan Adhikari, the leader of UML, was appointed prime minister, in his capacity as the leader of the largest party in the house, since no two or three parties could come together with a working majority.

The UML led minority government remained in power only for nine months. Political observers believed that the communist government was pursuing a populist policy in preparation for the next general election. Fearing that the UML will get an absolute majority in the next election, the parties in opposition i.e., NC, NDP, and Sadbhavana tabled a no confidence motion against the government. To avoid his government's defeat in the house, the prime minister quickly recommended the dissolution of the house, but his action was challenged in the Supreme Court, despite the fact that the king had already dissolved the house on the recommendation of the prime minister. The Supreme Court, by a majority of eight to three, decided the case against the government, arguing that the dissolution should take place only when no alternative was left for the formation of the government. The parliament was re-convened and as expected, the government was defeated at the floor and was bound to resign in September 1995. ${ }^{9}$

The NC, NDP, and Sadbhavana - led coalition government was formed under Sher Bahadur Deuba (a second grade leader of NC), and it stayed in power for 18 months. One significant political development during this period was the launching of the "people's war" by Nepal Communist Party (Maoist), which as a part of United People's Front had captured nine seats in the first general election but could not open its account in the second election. With an aggressive policy and violent method to implement it, the party submitted a 40 -point demand to the government, with an ultimatum to fulfill them within three months. Considering it a minor uprising, the government completely ignored the ultimatum, and the Maoist movement started in February 1996.

The Maoist movement, however, failed to gain any momentum, and two attempts by parties in opposition to topple the government also failed. However, dirty party politics continued and finally it led to the fall of Deuba's government in March 1997, after failing to secure a vote of confidence in the lower house. 
Between March 1997 and April 1999, the political instability in the country was at its worst, and five different governments were constituted during these two years. Furthermore UML, the largest party in parliament, was split into two factions. It was under these circumstances, the third general election was announced to be held in May $1999 .{ }^{10}$

\section{The Third General Election and After}

The results of the third general election gave new hope of political stability in the country. Unlike the second general election, the people did not vote for a hung parliament, rather they once again gave mandate to the Nepali Congress to rule and the leftist parties to sit in the opposition. The NC got 112 seats, commanding absolute majority in the house of 205, and the leftist parties emerged as main opposition force with 77 seats. Another positive aspect of the election was the total discard of breakaway parties and independent candidates by the people. Out of 633 independent candidates who contested, not a single seat was won. The people gave the verdict in favour of political stability, and completely neglected the breakaway parties, despite the name and fame the leaders of those parties enjoyed. This compelled the breakaway parties to rejoin the parent organizations.

Krishna Prasad Bhattarai was appointed prime minister in the new NC government. Girija Prasad Koirala who had earlier officially announced Bhattarai to be the new prime minister if the NC won the election, remained true to his words, but the only warning he gave to Bhattarai was that the prime minister should seek confidence of all the groups within the party. Some political observers then believed it as only a pretext on Koirala's part to stage a comeback, and their view came true, when within few months, Koirala charged Bhattarai with mishandling the country's politics, on the advice of few confidents. Koirala manipulated the situation in such a way that Bhattarai had to vacate his seat within ten months. ${ }^{11}$

Girija Prasad Koirala then assumed the prime ministership for the next sixteen months. During this period two major events, the Maoist insurgency and royal massacre, threw the country to a total disarray. As stated earlier, the Nepal Communist Party (Maoist) had started their "people's war" in February 1996, following the indifferent attitude of the Nepal Government to their 40-point demand. For the first few years it did not gain any momentum, but by the turn of the century it attracted thousands of unemployed youths to their side and they were able to establish firm control in far western districts. It was at this critical stage that on 1st June 2001 an unimaginable tragedy - the killing of the king and his family in the royal palace rocked the country. The crown prince was held responsible for the massacre, and the official report said that the crown prince shot himself after the destruction of his family. ${ }^{12}$ The direct impact of the royal massacre was the accession to the throne by Gyanendra, the only surviving brother of King Birendra, who was known for his conservative attitude in the past. Within two months, Koirala was forced to resign, as the new king "did not give him the opportunity to suppress the Maoist movement with the help of army. ${ }^{13}$ 
On the day Sher Bahadur Deuba was appointed the new prime minister, he publicly appealed the Maoist leaders to come to the negotiating table "in the interest of the country". The Maoist leader Prachanda, immediately responded by announcing cease fire, but the negotiations that took place in the next four months between the government and the Maoist leaders ended only in failure. The Maoists claimed that the government engaged the negotiating Maoist members on only peripheral matters, neglecting to enter into the political agenda despite the repeated requests made by the Maoist leaders for the same, whereas the government blamed the Maoist side of leaving the negotiation table suddenly without any reason. Whatever might be the reason, hostilities resumed and thousands of Nepali people lost their lives. The country was put under the state of emergency, army was mobilized to suppress the Maoists, and the government enacted the anti-terrorist laws to deal with the situation. ${ }^{14}$

When the question of the extension of emergency came in 2002, the ruling party (NC) was divided on the issue. The party president, Girija Prasad Koirala, opposed the extension, as it minimized the fundamental rights of the people. Koirala's contention was that the anti-terrorist laws gave enough power to the government and the army to deal with the Maoist affairs, and the extension of emergency period would adversely affect the working of the democratic institutions of Nepal. But the army, backed by the palace, insisted that the successful military operation would be possible only under the emergency rules, and argued that the fundamental rights of the general people were never ignored during the emergency period. Deuba was in a fix. It was not possible for him to serve the two masters viz. king and party president, heading towards opposite direction. Whether he chose the king or the party president, Deuba's post as prime minister was equally at risk. The history of Nepal would have taken a different turn, if the king and the ruling party had amicably solved the issue. There would have been no substantial change in the situation whether the emergency period was extended or not. But after failing to find a solution, the country entered into a new arena of crisis. Deuba, suspicious of Koirala's intention, sided with the king and recommended the dissolution of the house. ${ }^{15}$ The formal split in the ruling party, immediately after the house was dissolved, made the position of Deuba much weaker, but he was determined to conduct the general election within six months, as prescribed by the constitution, possibly with a hope to remain as prime minister.

But the sudden dissolution of the house created a great panic in the political circle. The NC could not believe that its own prime minister would take such a drastic step. The UML was not in a position to go to the polls, as it had just recovered from the stigma as a divided party. The other parties were also less prepared for the election. Most importantly, no one could foretell a free and fair election, in the midst of the army- Maoist clashes. In such a critical situation, the political parties firstly tried to declare the dissolution of the house as unconstitutional, through the judicial procedure, but when the supreme court upheld the decision of the prime minister as constitutionally valid, the political leaders in one voice asked the postponement of the election, in view of the law and order situation prevailing then in the remote areas. 


\section{King Assumes Executive Authority}

At first, the government showed its full determination to hold election in time, and the election commission had even announced the election schedule to be completed in six phases. But the constant demand by political parties to postpone the election because of Maoist activities finally forced Deuba's government to give in, which recommended the postponement of election by fourteen months. This provided a good opportunity for the king to move against the incumbent government. The postponement of the election was seen as a selfish move by the prime minister to remain in power. And on 4th October 2002 the king dismissed the Deuba government and took over the executive power to himself, thus clearly violating the provisions of the constitution. ${ }^{16}$ The major political parties were very mild in opposing the king's action, possibly with hope that the king would constitute an all party government with the major parties getting a lion's share. They demanded the formation of an interim government representing the major political parties of the dissolved house, but could not provide a common candidate for premiership. The king moved on his own way. After a week of silence, he constituted a cabinet completely ignoring the major political parties. He appointed a new prime minister, named Lokendra Bahadur Chand, a noted royalist and NDP leader who did not enjoy even the support of his own party. The other members were drawn either from minor parties or from bureaucrats and technocrats. ${ }^{17}$ When the cabinet was expanded after five weeks (18 November 2002), the major political parties were once again humiliated with the deserters or expelled members of the parties joining the cabinet.

With the assumption of executive power by the king, the political scenario of the country underwent substantial changes. Civic receptions to honour the king were organized in the eastern and western regions, and the media highlighted the role of the monarch in an exaggerated manner. The ministers used high sounding words to glorify the crown and attack the political parties, and the socio-religious groups were encouraged to organize programs in the name of the king. Holding of general election became an issue of secondary importance, as the King's cabinet was given a lot of responsibilities including maintenance of law and order, economic development, eradication of corruption, and good relations with neighbours and others.

One most positive development during this period was the ceasefire announcement by the Maoist leadership on 29th January 2003 in response to the "government's withdrawal of its earlier stand of treating them as terrorists." It seems that the king himself had taken the initiative to bring the Maoists to negotiation through the initiative of one cabinet member, Narayan Singh Pun. But the rest of the cabinet was not aware of this development. The political parties were also totally neglected, but even then they endorsed the proposal. A code of conduct was prepared and signed, and two rounds of talks were held in April and May 2003 between the government and Maoist teams.

Another development during this interim period was the launching of a movement by the five political parties including NC and UML for the restoration of democracy in Nepal. The 
NC demanded the restoration of the dissolved house of parliament, while the UML asked for the formation of an interim government, representing the major political parties. The movement did not succeed, but one indirect outcome of it was the resignation of Lokendra Bahadur Chand as prime minister in the month of May. King Gyanendra then asked the political parties to suggest a common candidate to head the new government. The NC and UML, which controlled nearly ninety percent seats in the dissolved house recommended Madhav Kumar Nepal, general secretary of UML, to the post of prime minister, but he was unacceptable to the king, who then appointed Surya Bahadur Thapa, a royalist and NDP leader to head the new government. Thapa tried his best to include representatives from both major and minor political parties in his cabinet, but did not succeed. Eventually, he had to constitute a small cabinet of seven persons, all drawn from his party the NDP.

One of the first things the cabinet did, was to hold a third round of talks with the Maoists on "political agenda", which, however, failed on the question of the "election of constituent assembly", and a new situation of confrontation began, with the Maoists making violent attacks on police, army, and even common people, and the government suppressing them with full military force.

From April 2004, the five major political parties started a new series of mass opposition through demonstrations and strikes, which was actively supported by the professional organizations of university teachers, doctors, engineers, artists, and even the government employees. After failing to put down the movement, Thapa resigned on 7th May. But the appointment of a new government proved to be a most difficult task. However after four weeks of moves and counter moves, a new Prime Minister Sher Bahadur Deuba was appointed, but it took another five weeks to constitute a cabinet. Deuba who had dissolved the parliament two years earlier at royal instigation, was now directed to start the electoral process by mid - April 2005.

Deuba knew it well that he would not be able to control the situation with opposition from two major political parties - NC and UML. The alliance with NC was impossible, and so Deuba convinced UML to join the government by offering its leader the post of deputy prime minister. The new cabinet called the Maoists repeatedly for dialogue, but the latter rejected the offer outright, sometimes arguing that they wanted direct talks with the king who actually controlled the state affairs, and other times challenging the government to prove its executive authority. The confrontation between the state forces and the Maoists continued, resulting in the death of hundreds of people from both sides.

On 25th November 2004, the cabinet finally gave a 50-day ultimatum to the Maoists to come to the peace talks, failing which the government would start the election process without the Maoists. But within three days, the Maoist supremo, Prachanda, ruled out any peace talk with the government, arguing that the peace talks could only be held under international mediation, and the election of constituent assembly would be their bottom line to solve the political crisis. 
The failure of Deuba to tackle the Maoist problem gave King Gyanendra the opportunity to impose his direct rule. On 1st February 2005 the king struck suddenly. He sacked the prime minister and imposed his direct rule with a cabinet of his choice under his own chairmanship. Most of the ministers, including two vice chairman, were drawn from the politicians and bureaucrats of the panchayat days. ${ }^{18}$ State of emergency was declared, fundamental rights were suspended, telephone lines were cutoff (for the first time in the history of Nepal), and media became the main target of the government. ${ }^{19}$

The major political parties opposed the king's action and started agitation for the revival of the dissolved house, but to no avail. Instead, the king formed a high-level anti- corruption commission, which implicated some politicians, including former Prime Minister Deuba, on corruption charges. Moreover, the government brought an ordinance curtailing the power of the journalists and media, and announced the municipality council elections, knowing fully well that the political parties would boycott them.

Under such a situation, the Maoists and the political parties thought it inevitable to come together to fight the king's autocratic rule, and in bringing them together, the Indian government played a vital role. On $22^{\text {nd }}$ November 2005, under the mediation of Indian government, the seven agitating political parties and the Maoists signed a 12-point understanding in New Delhi pledging to end the autocratic rule of the king and establish purna loktantra (a republic). ${ }^{1}$ The Nepal government did not make any official statement on this move. It seems that there was a difference of opinion among the ministers and royal advisors on the issue. An advisor to the king, Satchit Shamsher, branded the seven political parties as "terrorists", because "they made an alliance with the terrorists", whereas the Home Minister, Kamal Thapa, argued that the government "cannot put the Maoists and the political parties on the same footing."

Meanwhile, certain events put the king and his government in an awkward position. People boycotted the municipal elections, limiting the voters' turnout less than twenty percent in many places. Next, the Supreme Court declared the king-formed anti-corruption court illegal invalidating all of its decisions. And thirdly, the Maoists' violent activities continued in different parts of the country. Even at this stage, King Gyanendra showed no sign of negotiating. He simply asked the political parties to come to dialogue and advised the Maoists to come to main stream politics, possibly with the assumption that the opposition group would loose their strength within a short period. But the king's view of the situation proved to be false, when the agitating political parties with the active support of the Maoists started a mass movement in the first week of April 2006. Within 19 days, the movement took such an unprecedented turn with the participation of thousands of people that the king had to submit before the people, and was forced to reconvene the dissolved house of parliament. The house, for its part made a 25-point declaration which deprived the king of all powers -nominal and real-and vested supreme power of the state and government to the cabinet and parliament. ${ }^{21}$ 


\section{Nepal Becomes a Republic}

Unconfirmed reports say that when King Gyanendra reconvened the dissolved house on 24th April 2006, the NC and UML had assured him that they would not abolish the kingship, rather would go with constitutional monarchy. But the Maoists were strict on the abolition of monarchy as early as possible. They knew that the Maoists would be the first victim, if the king re-emerged in politics. Finally, a compromise was made in the interim constitution (promulgated in January 2007) by which the king was stripped of all power, and the fate of monarchy was to be decided in the first meeting of the elected constituent assembly. A new legislature was constituted with Maoists representation in sufficient numbers. They constantly demanded the abolition of monarchy by the house. When Prime Minister Giraja Prashad Koirala hinted at the possibility of installing a baby king (the infant grand-son of King Gyanendra), he came under such a massive attack that he had to withdraw his words. Once again a compromise was made through which the house was empowered to declare Nepal a republic, if the king in any way tried to obstruct the election of constituent assembly. The Maoists were not satisfied even at this stage. Finally, through a third amendment to the interim constitution (December 2007), Nepal was declared a republic with a provision that it should be ratified in the first meeting of the constituent assembly for implementation. ${ }^{22}$

The election of constituent assembly was postponed twice. The first postponement took place because of the "lack of time for preparation", and it was postponed for the second time due to the controversy on proportional representation among the Maoists and other political parties. Finally, the election took place in April 2008. Contrary to expectation, the Maoists captured 120 out of 240 elected seats and emerged as the largest party. In its first meeting on 28th May 2008, the country was formally declared a republic.

\section{Conclusion}

The abolition of monarchy was almost an unimaginable event in the history of Nepal. Even the Maoists would not have thought that the establishment of a republic would one day be realised. Three factors were largely responsible for this. First, King Gyanendra's ambition to be a dictator by completely ignoring the political parties including the Maoists. Secondly, there was an union between the Maoists and other the political parties against the autocratic rule of the king. Thirdly, the decisive role of Indian government to end the king's rule.

Monarchy was abolished, and a republican state was founded, but the political parties, including the Maoists have not been able to put the state in a right path to development. Their activities during the last six years compel us to believe that they can neither govern the country in a republican style, nor frame a democratic constitution for the nation. Although the constituent assembly had extended its term from two to four years but have not been able to even draft a constitution. The second constituent assembly (elected in November 
2013) pledged to promulgate a democratic constitution latest by January 2015, but every one believes that the peoples' representatives are giving a false assurance. To say it in straight words, the future of the country is moving towards darkness.

\section{End Notes}

1 Brown, L. T. (1996). The challenge to democracy in Nepal. London: Routledge. p.144.

2 Hutt, M. (1994). Nepal in the nineties. Delhi: Oxford University Press. p. 32.

3 Hoftun, M., William, R., \& John, W. (1999). People, politics, and ideology: Democracy and social change in Nepal. Kathmandu: Mandala Book Point. p. 54.

${ }^{4}$ Ibid., p. 55.

5 Brown, n.1, p.153

${ }^{6}$ For details see Malagodi, Mara. (2013). Constitutional nationalism and legal exclusion. New Delhi: Oxford University Press.

7 Hoftun, M., William, R., \& John, W. (1999). People, politics, and ideology: Democracy and social change in Nepal. Kathmandu: Mandala Book Point. p.182.

8 Ibid., p.197

9 Sharma, Jan.(1998). Democracy without Roots. Delhi: Book Faith India. p. 286.

${ }^{10}$ Whelpton, J. (2005). A history of Nepal. Cambridge: Cambridge University Press. pp. 197-99.

${ }^{11}$ Ibid., pp. 208-9.

${ }^{12}$ Many books have been published on the Royal Massacre, such as Jonathan Gregson (2002), Neelesh Misra (2001), Prakash A. Raj (2001) and Aditya Man Shrestha (2001).

${ }^{13}$ Whelpton, n.10, pp. 216-18.

${ }^{14}$ Jha, Prashant. (2014). Battles of the new republic. New Delhi: Aleph Book Company. pp. 45-46.

${ }^{15}$ Ibid., p. 52.

${ }^{16}$ Sudhir Sharma. (2013). Prayogsala:Nepali Sankramanma Delhi, Durbar ra Maobadi. Kathmandu: Fine Print, 2070 BS, p.125.

${ }^{17}$ Jha, n.14, p. 53. 
${ }^{18}$ Toffin, Gerard. (2013). From Monarchy to Republic. Kathmandu: Vajra Books. p. 50.

${ }^{19}$ Sharma, n.16, pp. 177-78.

${ }^{20}$ Ibid., pp. 223-24.

${ }^{21}$ Ibid., p. 240.

${ }^{22}$ For different amendments on Interim Constitution see Nepalko Antarim Sambhidhan, Kathmandu: Prerana Prakashan, 2063BS.

\section{References}

Brown, L. T. (1996). The challenge to democracy in Nepal. London: Routledge.

Gregson, J. (2002). Blood against the snow: A tragic story of Nepal's Royal Dynasty, London: Fourth Estate.

Hoftun, M., William, R., \& John, W. (1999). People, politics, and ideology: Democracy and social change in Nepal. Kathmandu: Mandala Book Point.

Hutt, M. (1994). Nepal in the nineties. Delhi: Oxford University Press.

Jha, P. (2014). Battles of the new republic. New Delhi: Aleph Book Company.

Malagodi, M. (2013). Constitutional nationalism and legal exclusion. New Delhi: Oxford University Press.

Manandhar, T. (1990). The Constitution of 1990: Making and implementation. In Political instability in Nepal, Kathmandu: Central Department of History.

Nepalko Antarim Sashan Bidhan 2063BS (Interim Constitution of Nepal 2007), Kathmandu: Pairavi Prakashan, 2063BS (Nepali).

Misra, N. (2001). End of the line: The story of the killing of the royals in Nepal. New Delhi: Penguin Books.

Raj, P. A. (2001). The Royal Massacre in Nepal. New Delhi: Rupa and Co.

Sharma, J. (1998). Democracy without Roots. Delhi: Book Faith India.

Sharma, S. (2013). Prayogsala:Nepali Sankramanma Dehli, Durbar ra Maobad (Place of Experiments: Delhi, Palace, and Maoists in Nepal's Transition) Kathmandu: Fine Print, 2070 BS (Nepali). 
Shrestha, A. M. (2001). The dreadful night: Carnage at Nepalese Royal Palace. Kathmandu: Ekta Books.

Toffin, G. (2013). From monarchy to republic. Kathmandu: Vajra Books.

Whelpton, J. (2005). A history of Nepal. Cambridge: Cambridge University Press. 
